\title{
The Relationship of Learning Outcomes of Learning Competence with the Implementation of PKM in Training Schools
}

\section{Lilies Yulastri and Eti Herawati}

Vocational Education Program, Health and Beauty Studies Program, State University of Jakarta, Jakarta, Indonesia

\section{Abstract}

The purpose of this study was to determine the relationship of learning outcomes of learning competencies with the implementation of the practice of teaching skills in training schools. This study was carried out in the Jakarta State University teaching skills practice unit, schools were used as training schools, regional education offices, and Jakarta State University. This research is a descriptive research that is trying to express what happened in the field to a starting point and how to develop further. While

Corresponding Author:

Lilies Yulastri

liliesyulastri@yahoo.com

Received: 11 January 2019

Accepted: 14 February 2019

Published: 25 March 2019

Publishing services provided by

Knowledge E

(c) Lilies Yulastri and Eti

Herawati. This article is

distributed under the terms of

the Creative Commons.

Attribution License, which

permits unrestricted use and

redistribution provided that the

original author and source are

credited.

Selection and Peer-review under the responsibility of the 3rd ICTVET 2018 Conference Committee. the research method used the survey method, the research sample was carried out by using purposive sampling technique, taking into account the elements contained in the population. Data analysis techniques used descriptive analysis and inferential analysis. This study found a relationship between learning outcomes of learning potential with the implementation of the practice of teaching skills in schools. So that the subject of learning competence can develop and improve. The result shows that there is a significant relation between learning competence with the implementation of PKM in training schools.

Keywords: learning competence, the practice of teaching skills, PKM (Praktek Keterampilan Mengajar), Teaching Skills Practice

\section{Introduction}

The current era of globalization raises competencies in various fields of economic, political, cultural, social and education. Conditions like this require people to be aware of all the capabilities they have to able to face these challenges. The contribution of ability and creativity one of the factors that can change people's lives for the better. Therefore, now what needed how to create a better life through quality human beings. Quality human beings include physical, mental and spiritual aspects.

Discussion of the quality of human resources, education plays a significant role in the S OPEN ACCESS process of improving the quality of human resources. Improving the quality of education 
a process that integrated with the process of improving the quality of human resources themselves. Recognizing the importance of the process of improving the quality of human resources, the government together with the private sector has continuously tried to realize the mandate through various efforts to develop higher quality education, among others through the development and improvement of curriculum and evaluation systems, improvement of educational facilities, development, and procurement of teaching materials, and in fact, the government's efforts have not meaningful enough to improve the quality of education.

Educational institutions one means to help the community. Educational institutions can also say to agents of community reform even individual or group changes. Indonesian people who expected at this time human beings who able to develop their overall potential.

Seeing such an essential role in education, the emergence of formal education can be seen as one of the government's efforts to improve the level of education of the population in various countries, including in Indonesia. National Education System Law No. 20 of 2003 , confirms that the education process can take place in the school and outside the school. Within the school environment, itself can take place in the classroom or outside the classroom. While education outside of school can take place in a family environment (informal) or the community (non-formal). Education outside of school usually referred to as non-formal education.

As in Law No. 20 of 2003, article 26 paragraph 1 explains that non-formal education held for citizens who need education services that function as substitutes, adders and equivalent formal education in order to support lifelong education. Furthermore, in paragraph 2 it explained that formal education functions to develop the potential of students (learning citizens) with an emphasis on mastering functional knowledge and skills and developing professional attitudes and personalities. Non-formal education an effort that organized systematically and continuously outside the school system, through social relations to guide individuals, groups and communities in order to have active social attitudes and ideas in order to improve living standards in the material, social and mental fields to realize social welfare [1].

The more complex the national education system is, the more complex the management system will be. Education not only in educational institutions, courses, and families but also in various social groups. This all requires careful and thoughtful attention and thought about the management system needed. However, wherever the educational process carried out, in the school environment or outside of school, in 
essence, develops the potential of human resources. The goal pursued through what called learning activities.

The implementation of learning activities in non-formal education not much different from formal education in general. In learning activities, good management needed because of the management an effort to succeed in a goal in learning.

Learning management includes learning planning, learning implementation, and learning evaluation. These three principles cannot separated. This because the success of learning depends on how a leader can manage management learning well starting from the planning, implementation, and evaluation.

The results of the learning activity process can been seen from the competencies achieved by students. As for in this study what meant by student competence the level of achievement in mastering the material after taking the learning process and being able to apply it in daily life.

Efforts to able to educate, develop individuals and anticipate existing educational problems, students required to recognize and understand their profession as teaching staff. Therefore, students given the burden of basic education courses namely courses that aim to provide the basics of education that function primarily to develop attitudes and professional educational insight. The courses given consist of four courses, namely the Introduction to Educational Sciences. The courses given consisted of four subjects, namely the Introduction to Education, the Development Psychology subject, the Learning and Learning Theory, and the Education Professional course.

Along with the rapid development of science and technology, more and more skilled and professional workers needed in their fields. For education, a teacher needed who has skills in various fields. So it can ascertain that the more qualified teaching staff, the higher the contribution to the development of their students. Qualified teaching staff able to act as leaders in their groups of students and among their peers. So in broad outline the image of qualified teaching staff, namely individuals who prepare themselves specifically through teacher education institutions, so that with their expertise to able to teach as well as educate their students to become good citizens, knowledgeable, productive, social, healthy and able to play a role in improving human Resources.

Jakarta State University one of the LPTKs and tasked with producing educators who professionally face the need to educate, educate the next generation. One of the core academic activities that intra-curricular the Teaching Skills Practice (PKM) which will provide guided, integrated and integrated educational task training to fulfill the requirements for the formation of professional education personnel. PKM an integral 
part of the LPTK curriculum and the estuary of academic activities in the study program at Jakarta State University.

PKM LPTKs throughout Indonesia today take a block system. The definition of a block system a PKM implementation system that requires students to in schools/training places and to follow their activities during the hours of activities.

From year to year, the pattern of PKM is growing but there still many obstacles and various problems related to the context of finding a form/management system that oriented toward achieving the goals of PKM.

The achievement of this goal expected not only to give direct experience to students of PKM participants but also can a place of interaction between universities and the community (in this case the school) which will all lead to an increase in human resources (educational output).

The Jakarta State University Teaching Skills Program (PKM) and other state universities must attended by all undergraduate students. The core of the PKM program must relevant to the functions and tasks of a teacher, instructor, facilitator or mentor in the field. The continuity of the Pre-PKM program on campus and the implementation of PKM in the field expected to produce education professionals who able to realize "Link \& March" between LPTK study programs and needs in the community. The word competency according to Muslich interpreted as the power of ability, sense of power, and the power of action of someone who readies to actualized when facing the challenges of life, both now and in the future [2]. Meanwhile, the definition of competence according to Sa'udcan interpreted as an essential ability that can done by students at the stage of knowledge, skills, and attitude [3].

Competence basic knowledge, skills, and values that reflected in the habit of thinking and acting. The habit of thinking and acting consistently and continuously allows one to compete, in the sense of having the necessary knowledge, skills, and values to do something. A person declared competent in a particular field if the person mastering work skills/expertise that in line with the demands of the work field in question or in other words, he able to do tasks according to the required standards. The standards required depend on the demands of the work or the demands of the community which refers to world-class standards. According to Finch and Crunkilton quoted by Mulyasa that what meant by competence mastery of a task, skill, attitude, and appreciation needed to support success. This shows that competencies include tasks, attitude and appreciation skills that students must possess to able to carry out learning tasks by certain types of work [4]. Based on some of the opinions above, it can concluded that 
what meant by competence the ability of students at the stage of knowledge, skills, and attitude to support success in facing the challenges of life.

Competencies that must mastered by students need to state in such a way as to assessed, as a form of student learning outcomes that refer to direct experience. Students need to know the learning objectives, and levels of mastery that will used as achievement criteria explicitly developed based on goals that have set and had a contribution to the competencies studied.

Assessment of achievement of competencies carried out objectively, based on the performance of students, with evidence of students' mastery of a learning outcome competency. In learning designed based on competence, an assessment not carried out based on subjective considerations.

According to Suparno ${ }^{5}$, quoting Johnson's opinion on competency-based teaching states "that competency-based teaching a system where students will only consider to have completed the lesson if they able to carry out the task he has learned to do. Knowledge, skills and attitudes the way for a performance." [5]. Meanwhile, Johnson views competence as a rational act that satisfactorily fulfills its objectives under the desired conditions. Rational actions said because people who do it must have a purpose/direction and know why they do it [5]. Meanwhile, according to Sa'ud competence the ability to do something different from just knowing something. Competence must demonstrated by the standards in the field [6]. Based on the above background, the researcher interested in researching the relationship between Learning Competency Learning Outcomes with the Implementation of Teaching Skills Practices (PKM) in the School of Exercise.

\section{Method}

The purpose of the study to analyze the relationship between Learning Outcomes of Learning and Appearance Competencies (Performance) Student Teaching Skills Practices (PKM) in the School of Exercise. This research conducted in the Jakarta State University PKM/PKM unit, namely schools used as training schools, regional education offices, and Jakarta State University. The research period in the odd semester of the academic year from August to October 2014. This research a descriptive study that trying to express what happened in the field to a starting point and how to develop further. While the research method used the survey method.

The population of this study all parties involved in the implementation of the Teaching Skills Program. The research sample carried out by using purposive sampling technique, 
taking into account the elements contained in the population. At the beginning of the study, a large sample of 40 people planned.

TABLE 1: Indicator of Research Instruments.

$\begin{array}{ll}\text { Research Aspect } & \text { Indicator of Research Problems } \\ \text { 1. MK PBM Organization } & \text { - Complete references } \\ \text { - Micro teaching Exercises } & \text { - Mastery of Material } \\ \text { - Qualifying Lecturer } \\ \text { - PKM Debriefing }\end{array}$

\section{Results}

Based on calculations performed using the SPSS version 22 application, the following descriptive statistics obtained.

TABLE 2: Descriptive Statistics.

$\mathbf{N}$
Implementation of PKM
Learning outcomes
Valid N (listwise)

\begin{tabular}{|c|c|c|c|c|}
\hline \multicolumn{2}{|c|}{ Minimum } & Maximum & Mean & Std. Deviation \\
\hline 40 & 137 & 194 & 168.63 & 14.709 \\
\hline 40 & 30 & 100 & 95.30 & 2.775 \\
\hline 40 & & & & \\
\hline
\end{tabular}

Based on the table above, the PKM Implementation obtained a mean value of 168.63 , a maximum value of 194 and a minimum value of 137 and a standard deviation of 14,709. In the variable learning outcomes obtained a mean value of 95.30, a maximum value of 100 minimum values of 30 , a standard deviation value of 2.775 , with a sample of 40 respondents.

\subsection{Test results for normality data measurement data}

Trials of normality on the results of measurements carried out using the Lilliefors/ Kolmogorov- Smirnov test. The number of samples taken in this trial as many as $\mathrm{N}$ $=40$ samples. 


\subsection{Normality data}

To calculate the normality test, the Lilliefors formula used. The hypothesis proposed in the normality test in $\mathrm{H}_{o}$ derived from a population that normally distributed and the alternative that the data does not come from a population that normally distributed, the criteria for testing the hypothesis with a significance of $\alpha=0.05$ and $n=40$, namely:

Accept Ho if $P$-value $>\alpha 0.05$

Reject Ho if $P$-value $>\alpha 0.05$

The results of normality testing on PKM implementation variables from the Kolmogorov-Smirnov distribution normality test obtained. The results of PKM implementation $P$-value $=0.200>0.05$, it can conclude that the sample on the PKM implementation variable normally distributed. For the results of testing the normality of the learning variables of the Kolmogorov-Smirnov distribution normality test, the results of the learning result $P$-value $=0.200>0.05$, it can conclude that the sample on the variable learning outcomes normally distributed. The data above can be seen in the following Table 3.

TABLE 3: Calculation of Normality Results with Lilliefors Variable. Test

\begin{tabular}{|c|c|c|c|}
\hline \multicolumn{2}{|c|}{ One-Sample Kolmogorov-Smirnov Test } & \multirow{2}{*}{$\begin{array}{c}\text { Implementation of } \\
\text { PKM } \\
40\end{array}$} & \multirow{2}{*}{$\begin{array}{c}\text { Learning } \\
\text { outcomes } \\
40\end{array}$} \\
\hline $\mathrm{N}$ & & & \\
\hline \multirow[t]{2}{*}{ Normal Parameters ${ }^{a, b}$} & Mean & 168.63 & 95.30 \\
\hline & Std. Deviation & 14.709 & 2.775 \\
\hline \multirow[t]{3}{*}{ Most Extreme Differences } & Absolute & 0.085 & 0.082 \\
\hline & Positive & 0.042 & 0.071 \\
\hline & Negative & -0.085 & -0.082 \\
\hline Test Statistic & & 0.085 & 0.082 \\
\hline Asymp. Sig. (2-tailed) & & $0.200^{c, d}$ & $0.200^{c, d}$ \\
\hline
\end{tabular}

To determine the linearity assumptions, it can see from the Ujianova ( $F$ overall) if the $P$-value of the test results $\leq$ alpha, the average value of $Y$ linear from $X$ (the model linear). Statistical tests for regression coefficients can be seen in the ANOVA Test column Sig $\mathrm{F}$ and produces $P=0.000$. So alpha $=5 \%$ means rejecting the null hypothesis means there a linear relationship between PKM Implementation with learning outcomes. This can be seen in the table below. 
TABLE 4: Linearity Test.
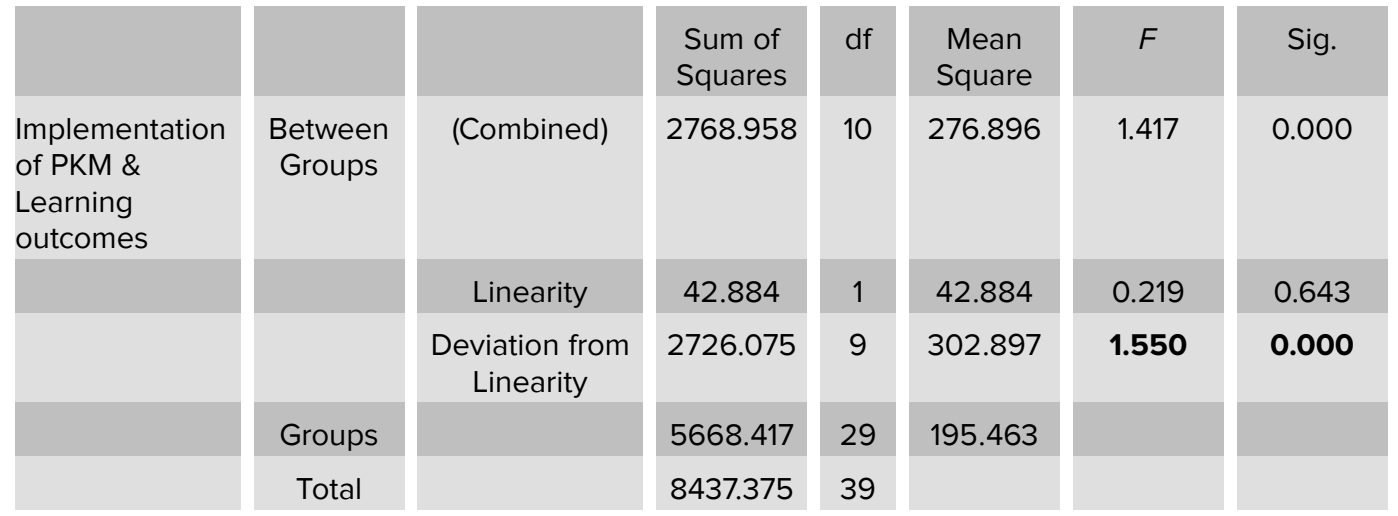

\subsection{The relationship between learning competency learning outcomes and implementation of PKM}

Implementation From the results of the correlation test between the results of learning competencies and the implementation of PKM that have carried out, as shown in Table 4 there a positive relationship between learning outcomes and the implementation of PKM with the correlation coefficient and Pearson product moment (r) obtained at 0.678 and the relationship shows a strong relationship between the implementation of PKM and learning outcomes, as well as in a direction and positive manner.

TABLE 5: Correlation Analysis.

Variable
Implementation of PKM \&
Learning outcomes

\begin{tabular}{|c|c|}
\hline $\mathbf{R}$ & $\mathbf{R 2}$ \\
\hline 0.678 & 0.460 \\
\hline
\end{tabular}

Regression Equation
$Y=173.840+3.594 X$
P-value 0.000

From the results of simple regression analysis that has carried out between the dependent variable $\mathrm{Y}$ and the independent variable $\mathrm{X}$, as shown in Table $4 \mathrm{R}$-Square $=0.460$ as the coefficient of determination, which in this case means $46 \%$ of learning outcomes influenced by the implementation of PKM, while $54.0 \%$ influenced by other factors.

From the ANOVA test or $F$ test, it found that $F$ hit 32,340 with a significance level of 0.05 . Because probability or $P$-value $=0.000$ much higher than 0.05 , or $P$-value $<0.05$; $0.000<0.05$ then Hypothesis Null (Ho) rejected, then the conclusion of this study that there a positive relationship between learning competency learning outcomes and the implementation of PKM. 


\section{Discussion}

PKM a course that must take by all Jakarta state university students who enter the first level of education. PKM implemented in order to equip students to practice teaching in schools. Before conducting PKM, students get supporting courses, namely learning competency courses, with the aim of students having the provision to appear in front of the class.

Learning competency courses that the basis for the implementation of PKM in schools contains material about the competence of teacher teaching skills, preparing lesson plans and various teaching skills in the classroom. This study found a relationship between learning outcomes of learning potential with the implementation of PKM in schools. So that the subject of learning competence can developed and improved.

\section{Conclusion}

This study found a significant positive relationship between the results of learning competencies with the implementation of PKM in schools. Where the better the results of learning competence, the better the implementation of PKM in school by students.

\section{Funding}

Funding obtained from the Public Service Agency (BLU), Faculty of Engineering.

\section{Acknowledgement}

We would like to thank the dean of the faculty of engineering, vice dean 1 faculty of engineering, coordinator of the health and beauty vocational study program where the research carried out.

\section{Conflict of Interest}

The authors have no conflict of interest to declare.

\section{References}

[1] Mustofa Kamil. Pendidikan Nonformal, Bandung: Alfabeta. 2009. 
[2] Muslich. Kurikulum Berbasis Kompetensi, Jakarta: Rineka Cipta. 2004.

[3] Sa’ud, Udin Syaefudin, Inovasi Pendidikan, Bandung: Alfabeta, 2004.

[4] E. Mulyasa, Kurikulum Berbasis Kompetensi, Bandung: Remaja Rosdakarya, 2004.

[5] Suparno, Kompetensi Belajar Mengajar, Jakarta: Bumi Aksara, 2001.

[6] Saud, U. S. Inovasi Pendidikan, Bandung: Alfabeta, 2009. National Education Republic of Indonesia. Act of the republic of Indonesia number 20, year 2003 on national education system. Jakarta. 2003. 